\title{
Towards reduced reliance on fungicides for disease control in New Zealand's crop-based industries
}

\author{
R.M. Beresford \\ The New Zealand Institute for Plant \& Food Research Ltd (Plant E Food Research), \\ Mt Albert Research Centre, Private Bag 92169, Auckland 1142, New Zealand \\ Corresponding author: robert.beresford@plantandfood.co.nz
}

\begin{abstract}
The challenge faced by New Zealand's fruit, vegetable and arable sectors is to reduce the negative impacts of fungicides on market access, environmental sustainability and consumer confidence, while at the same time achieving adequate disease control for export market and international regulatory requirements. Controlling diseases in a humid climate with ever increasing restrictions on agrichemicals and few effective alternatives to fungicides requires re-design of disease management systems. Research into re-design includes improved resistance of crop cultivars, improved understanding of microbial interactions between fungicides, biological controls and non-target microbes and completely novel methods based on molecular genetics. Disease forecasting systems can improve the efficiency of fungicide use. The success of new approaches must measured by a reduction in fungicide loading. Success depends on the linking of new research to effective technology transfer that will give crop-based industries courage to try new methods and the confidence to know they are not risking their economic viability.
\end{abstract}

Keywords fungicide loading, fruit, vegetable, arable, low-input agricultural systems.

\section{INTRODUCTION}

Airborne fungal and bacterial pathogens cause economic losses to most crop plants (Knight et al. 1997). This may be through destruction of photosynthetic area leading to yield reduction, structural plant damage, cosmetic downgrading of products or postharvest spoilage. In addition, some plant pathogens may prevent access to markets because they pose a phytosanitary threat, e.g. the potential disruption to citrus exports when it appeared the pathogen Guignardia citricarpa may be present in New Zealand (Everett \& Rees-George 2006). Many problematic diseases are successfully controlled by fungicides, but the fungicides themselves can have negative impacts, particularly through preventing access to markets because of chemical residue traces (Gullino \& Kuijpers 1994, Campbell \& Rosin 2007). New Zealand's export production faces increasing uncertainty over the future availability of fungicides as consumer awareness about health and environmental effects of agrichemicals increases. Retailers responding to this consumer awareness can arbitrarily dictate amounts and types of pesticides that are acceptable for food production (Kempthorne 2007). Reducing reliance on fungicides for crop protection is an immediate and crucial issue for many New Zealand industries.

This paper explores the challenges faced by crop-based industries when reduced reliance on chemical disease control becomes mandatory 
and examines alternatives to the use of chemicals for disease management. It focuses on fungicides used against airborne fungal diseases affecting fruit, vegetable and arable crops and discusses new areas of research that will help New Zealand industries find alternatives to chemicals for disease management.

\section{FUNGICIDES: A VICTIM OF THEIR OWN SUCCESS}

Fungicides can be extremely potent in inhibiting fungal pathogens and their field efficacy is often spectacular. For example, field trial data from grapevines in New Zealand (Figure 1) show how two fungicide applications made 2-3 months before disease symptoms of botrytis bunch rot appeared, substantially reduced disease development. Effective fungicide control has been reported for many pathosystems when fungicides with activity against a target pathogen are applied at suitable times. Recent examples in New Zealand include wheat stripe rust (Viljanen-Rollinson et al. 2006), avocado fruit rot (Everett et al. 2008) and botrytis flower blight of blackcurrant (Walter et al. 2007). Continual improvement in efficacy of synthetic fungicides over about 50 years has allowed modern agriculture to realise a productive potential that would not otherwise have been possible. It has also led modern agriculture to rely on fungicides. This reliance, coupled with concern over the use of chemicals in food production (Zitter 1984) and awareness of their negative environmental and human health impacts (Metcalf 1993), has made fungicides victims of their own success. Furthermore, a tendency towards overuse can lead to selection of fungicide resistance in plant pathogens and this threatens the ongoing usefulness of, particularly, more recentlydeveloped fungicides with site-specific modes of action (Brent \& Holloman 2007).

In New Zealand, as elsewhere, despite improvements in fungicide chemistry, use of older fungicides still predominates. For example, $80.3 \%$ of fungicide active ingredient currently applied in New Zealand horticulture (fruits and vegetables) consists of low-cost broad-spectrum inorganics (e.g. copper and sulphur) and

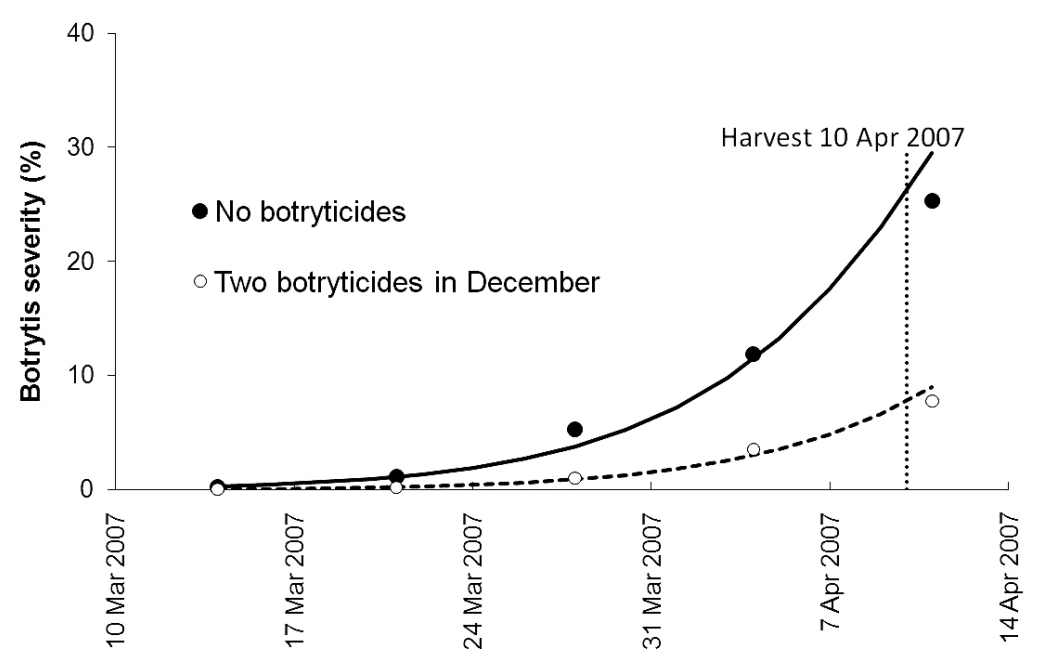

Figure 1 Reduction in the rate of disease progress for botrytis bunch rot (Botrytis cinerea) in Sauvignon blanc grapes resulting from two applications of a fungicide containing cyprodinil+fludoxinil. Two applications made to replicated experimental plots in December, 2-3 months prior to appearance of disease symptoms, reduced disease severity at harvest by about $16 \%$ compared with a control that received no fungicides (R.M. Beresford, unpublished data). 
dithiocarbamates (Manktelow et al. 2005). The preference for these has undoubtedly been cost driven and has been able to occur in the absence of urgency to change old practices. Because broadspectrum fungicides are used at high application rates and because there are environmental and health concerns over some of them, urgency for change is likely to develop rapidly. Modern fungicides are significantly more expensive and, because of their site-specific modes of action, are more likely to select pathogens with fungicide resistance. Broad-spectrum fungicides, particularly dithiocarbamates, are often used as mixing partners with modern fungicides as a strategy to reduce fungicide resistance risk (Martin et al.2005). It is not currently known how the removal of broad-spectrum fungicides from New Zealand's cropping industries would affect the economics of crop production. Profitability could be lower, unless the price of site-specific fungicides decreased markedly. Disease control could be difficult to attain because pathogen resistance would develop to many site-specific fungicides if cheap broad-spectrum mixing partners were not available.

\section{SYSTEM RE-DESIGN TO REDUCE FUNGICIDE RELIANCE}

Even though modern agriculture has high dependence on synthetic fungicides, some consider that they are not indispensible (Metcalf 1993). However, the development of fungicidedependent agriculture over the last 50 years has left us poorly equipped to find alternatives quickly. Many crop cultivars have been bred with little emphasis on genetic resistance to disease, and dependence on fungicides has required no scientific understanding of microbial ecology in production systems. Although the possibility of disease suppression by non-fungicide means has been considered for a long time, e.g. Blakeman \& Fokkema (1982), acceptable levels of disease control with non-fungicide approaches have not yet been achieved for the New Zealand crops that most rely on fungicides, e.g. onions, potatoes, cucurbits, stonefruit, avocadoes, apples and grapevines (Table 1). Biological control agents tend to have variable efficacy compared with fungicides, e.g. for control of Botrytis cinerea in grapevines (Elmer \& Reglinski 2006; Jacometti et al. 2010). It has also been found that, for postharvest fruit diseases, biological control agents cannot be used as simple fungicide substitutes (El-Ghaouth 1997).

A reduction in dependence on fungicides will require redesign of agricultural systems. This has been recognised and approached in many different ways (van Bruggen, 1995). The technological approach (de Haan et al. 2010) involves increased artificiality of the system, e.g. fertigation, plastic mulches and hydroponics. These have been successful for indoor crops, but there is no inherent reason why they would lead to reduced reliance on fungicides. The alternative ecological approach (de Haan et al. 2010) includes the philosophies of organic agriculture. It has been argued that organic agriculture (including bio-dynamic), is the only alternative to conventional agriculture that operates under a defined and certified system. Van Bruggen (1995) provides a balanced discussion of the advantages and disadvantages of organics in relation to disease control. Most system redesign for conventional production systems so far seems to have consisted of individual research groups seeking to understand components of alternative approaches to disease control, such as mechanisms of biological control (e.g. Elmer \& Reglinski 2006).

For New Zealand, agricultural system redesign is unlikely to occur as a revolutionary change because existing systems, which are finely tuned, must keep functioning economically and it would be dangerous to introduce untested new technologies. Re-design is more likely to occur in an evolutionary manner, with the rate of change and degree of success determined by the level of investment in research and technology implementation.

\section{SCIENCE FOR SYSTEM RE-DESIGN}

The most likely appearance of future agricultural systems that have reduced reliance on fungicides has been articulated by Russell (2005): 
"Plant disease control will remain a necessity and fungicides will remain as a key factor in such control, although it is predicted that integrated control using chemicals, biological controls and biotechnology approaches will begin to dominate".

To this can be added the need for improved genetic resistance of crop cultivars to diseases. Durable partial resistance may be more beneficial than high levels of oligo-genic resistance that are overcome quickly by new pathogen races. Research in New Zealand is identifying levels of partial resistance that can usefully reduce fungicide requirements for stripe rust (Pucciniastriiformis) of wheat(Viljanen-Rollinson 2010). The development timeframe for new resistant fruit cultivars is longer than for annual crops. Marker assisted selection is expected to speed this process and improve the effectiveness of resistance genes that are incorporated, e.g. for apple scab (Venturia inaequalis) in New Zealand (Bus et al. 2002).

Biological control agents, particularly fungi and yeasts, have been successfully implemented in New Zealand, e.g. for botrytis bunch rot control in the wine industry (Elmer et al. 2005). System redesign to achieve non-chemical disease control will require improved understanding of the microbial ecology of pathosystems, including the impacts of fungicides on non-target and potentially beneficial microbes. This is being addressed through the concept of restorative

Table 1 Annual fungicide loading for selected New Zealand crop sectors illustrating differences in amount and type of fungicide used in arable, vegetable and fruit crops. Data are from an unpublished report by Manktelow et al. (2005). Although not recent data, trends shown in the report suggest that loadings among these sectors are likely to have changed little since 2005.

\begin{tabular}{|c|c|c|c|c|c|c|c|c|}
\hline \multirow[b]{2}{*}{ Crop type } & \multirow{2}{*}{$\begin{array}{c}\text { Planted } \\
\text { area (ha) }\end{array}$} & \multicolumn{7}{|c|}{ Mean loading ( $\mathrm{kg}$ fungicide active ingredient/ha) } \\
\hline & & ${ }^{1}$ Dith. & ${ }^{2}$ Tria. & ${ }^{3}$ Dic. & ${ }^{4} \mathrm{QoI}$ & ${ }^{5}$ Benz. & ${ }^{6}$ Inor. & Other \\
\hline \multicolumn{9}{|l|}{ Arable } \\
\hline Wheat & 42,187 & & 0.16 & & 0.10 & 0.03 & & \\
\hline Forage brassicas & 10,000 & 0.38 & 0.01 & & 0.01 & & & 0.02 \\
\hline \multicolumn{9}{|l|}{ Vegetable } \\
\hline Onion/garlic & 5,948 & 17.37 & 0.51 & 0.08 & & 0.27 & 0.97 & 0.15 \\
\hline Potato & 10,931 & 14.92 & 0.01 & & 0.15 & & 0.08 & 0.43 \\
\hline Squash & 6,804 & 7.90 & 0.05 & & & & 3.32 & 0.40 \\
\hline \multicolumn{9}{|l|}{ Fruit } \\
\hline Grape (wine) & 19,646 & 0.93 & 0.02 & 0.10 & & & 3.69 & 1.74 \\
\hline kiwifruit & 12,357 & & & 0.30 & & 0.05 & 0.42 & \\
\hline Apple & 12,150 & 1.55 & 0.08 & & 0.08 & 0.05 & 0.75 & 2.88 \\
\hline Avocado & 3,235 & & & & & & 9.51 & \\
\hline Peach \& nectarine & 1,288 & 3.06 & & 0.58 & & 0.17 & 8.17 & 2.87 \\
\hline
\end{tabular}

${ }^{1}$ Dith.=dithiobarbamate (also known as EBDC).

${ }^{2}$ Tria. $=$ triazole and diazole.

${ }^{3}$ Dic. $=$ dicarboximide.

${ }^{4}$ QoI=Quinone outside inhibitor (also known as strobilurin).

${ }^{5}$ Benz.=benzimidazole.

${ }^{6}$ Inor.=inorganic fungicides (mainly copper and sulphur). 
biological control (Everett et al. 2005), which requires molecular techniques to be integrated with conventional microbiology to quantify microbial populations in orchards. The potential to manipulate host nutrition to influence susceptibility to disease is also important, e.g. the effect of nitrogen nutrition in grapevines on susceptibility of grape berries to $B$. cinerea (Mundy \& Beresford 2007). Other more novel approaches to disease control, such as use of fungal viruses, low-pathogenicity pathogen strains, enhanced host defences and exploiting fungal genomic data are also being researched in New Zealand (Beever et al. 2005).

Disease forecasting systems that use weather information to time fungicides only when they are needed have been in use since Mills identified the weather requirements for apple scab infection (Mills \& LaPlant 1954). A disease forecasting system for apple scab has been in use in New Zealand for about two decades (Beresford \& Spink 1992) and although it probably improves the efficiency of fungicide use (Laurenson \& Beresford 1996), the high susceptibility of commercial apple cultivars means that intensive fungicide spraying is still required. This results in the relatively high fungicide loading for apples (Table 1). For some crops, e.g. onions, disease forecasts that could be used have not been taken up widely because market drivers to reduce fungicide use appear to be lacking. Onions have the highest fungicide loading of any crop in New Zealand (Table 1), a substantial part of which comprises dithiocarbamates to prevent downy mildew (Peronospora destructor). Associations between weather and downy mildew risk have been established (Whiteman \& Beresford 1998), spraying strategies to use weather information to manage fungicide use have been developed (Wright et al. 2002) and a forecasting system has been implemented (Chynoweth et al. 2003). From this research it appeared that fungicide spraying for downy mildew was unnecessary in Franklin District in many seasons. Although this forecasting system is currently in use, it is operated by an agrichemical supplier to provide information about downy mildew risk to customers and, understandably, does not lead to recommendations for less fungicide use.

Determiningwhethernewdiseasemanagement technologies do in fact reduce reliance on fungicides is, in itself, challenging. It must be demonstrated, using industry-wide fungicide use data, that a new technology led to a reduction in fungicide loading. Promising results from scientific experiments are not a demonstration of success. In analysing trends in fungicide use, it is necessary to have accurate data on fungicide loading (amount of fungicide applied per unit of crop area). Total fungicide applied is of little value without accurate crop area data. Planted area of annual crops varies greatly from season to season. Crop inputs, including fungicides, vary with economic value of the crop and with yearto-year changes in profitability. These factors make it difficult to determine whether a change in fungicide loading was caused by a change in disease management or by a change in macroeconomic factors affecting crop profitability.

\section{CONCLUSIONS}

The impetus to redesign cropping systems with reduced reliance on fungicides for disease control will occur first in those crop sectors where fungicides result in chemical residues or environmental concerns that threaten markets. The implementation of alternative disease control technologies that are economically viable representsanenormousscientificand technological challenge. Slow progress has occurred over the last 30 years because the need to reduce fungicide use has not been there. Progress over the next 30 years will initially be hindered by a lack of knowledge, particularly about pathosystem ecology, and a lack of preparedness because of the high susceptibility of modern crop cultivars to diseases. A significant increase in research effort will be required before substantial progress can be made.

This review has attempted to put into perspective the important issues about reducing reliance on fungicides in New Zealand cropping systems to help design effective research and technology transfer programmes. Crop-based industries need courage to try new methods and 
they must have confidence that new methods do not put their economic viability at risk. The need to redesign agricultural systems is a worldwide issue that New Zealand does not face alone. However, changing perceptions about agrichemicals are a particular risk to New Zealand's agriculturedependent economy and New Zealand therefore needs to be a world leader in this field.

\section{ACKNOWLEDGEMENTS}

The "Low-Impact disease control" research programme is funded from 2008-2013 by The New Zealand Foundation for Research, Science and Technology (Contract C06X0810). Thanks are due to the three objective leaders, Drs Kerry Everett, Vincent Bus and Bob Fullerton, for their intellectual input into the design and execution of the programme, and to the more than thirty participating researchers in Plant \& Food Research, Landcare Research and AgResearch.

\section{REFERENCES}

Beever RE, Plummer KM, Wurms KV 2005. Novel approaches to controlling fruit pathogens. New Zealand Plant Protection 58: 68-73.

Beresford RM, Spink M 1992. A national disease forecasting system for apple black spot (Venturia inaequalis) in New Zealand. Acta Horticulturae 313: 285-296.

Bus V, White A, Gardiner S, Weskett R, Ranatunga C Samy A, Cook M, Rikkerink E 2002. An update on apple scab resistance breeding in New Zealand. Proceedings International Symposium on Apple Breeding for Scab Resistance. Bergamini A, Janick J, White A, Zeppa A, Giongo L ed. Acta Horticulturae 595: 43-47.

Blakeman JP, Fokkema NJ 1982. Potential for biological control of plant diseases on the phylloplane. Annual Review of Phytopathology 20: 167-190.

Brent KJ, Holloman DW 2007. Fungicide resistance in crop pathogens: how can it be managed? Fungicide Resistance Action Committee. FRAC Monograph No. 1 (second, revised edition). $56 \mathrm{p}$.

Campbell HR, Rosin CJ 2007. Global retailer politics and the quality shift in New Zealand horticulture. In: Future challenges in crop protection: repositioning New Zealand's primary industries for the future. Butcher MR, Walker JTS, Zydenbos SM ed. New Zealand Plant Protection Society Inc., Hastings, New Zealand. Pp. 11-25.

Chynoweth RW, Beresford RM, Henshall WR, Wright PJ 2003. Use of disease forecasting models for control of onion downy mildew in New Zealand. In: Advances in Downy Mildew Research Vol 2. Spencer-Philips P, Jeger M ed. Kluwer, Dordrecht, The Netherlands. Pp. 91-97.

De Haan J, Sukkel W, Stilma E 2010. Technology versus agro-ecology in designing vegetable productionsystemsintheNetherlands.In:Larsen RU ed. Proceedings of the 4th International Symposium on Ecologically Sound Fertilization Strategies for Field Vegetable Production. Acta Horticulturae 852: 123-129.

El-Ghaouth A 1997. Biologically-based alternatives to synthetic fungicides for the control of postharvest diseases. Journal of Industrial Microbiology and Biotechnology 19: 160-162.

Elmer PAG, Hoyte SM, Vanneste JL, Reglinski T, Wood PN, Parry FJ 2005. Biological control of fruit pathogens. New Zealand Plant Protection 58: 47-54.

Elmer PAG, Reglinski T 2006. Biosuppression of Botrytis cinerea in grapes. Plant Pathology 55: 155-177.

Everett KR, Vanneste JL, Hallett IC, Walter M 2005. Ecological alternatives for disease management of fruit rot pathogens. New Zealand Plant Protection 58: 55-61.

Everett KR, Rees-George J 2006. Reclassification of an isolate of Guignardia citricarpa from New Zealand as Guignardia mangiferae by sequence analysis. Plant Pathology 55: 194-99.

Everett KE, Timudo-Torrevilla OE, Hill GN, Dawson TE 2008. Field testing alternatives to copper for controlling avocado fruit rots. New Zealand Plant Protection 59: 65-69.

Gullino ML, Kuijpers LAM 1994. Social and political implications of managing plant diseases with restricted fungicides in Europe. Annual Review of Phytopathology 32: 559581. 
Jacometti MA, Wratten, SD, Walter M 2010. Review: Alternatives to synthetic fungicides for Botrytis cinerea management in vineyards. Australian Journal of Grape and Wine Research 16: 154-172.

Kempthorne RG 2007. Future challenges in horticulture. In: Future challenges in crop protection: repositioning New Zealand's primary industries for the future. Butcher MR, Walker JTS, Zydenbos SM ed. New Zealand Plant Protection Society Inc., Hastings, New Zealand. Pp. 37-39.

Knight SC, Anthony VM, Brady AM, Greenland AJ, Heaney SP, Murray DC, Powell KA, Schulz MA, Spinks CA, Worthington PA, Youle D 1997. Rationale and perspectives on the development of fungicides. Annual Review of Phytopathology 35: 349-372.

Laurenson MR, Beresford RM 1996. Decision support software as a medium for technology transfer in plant protection. Proceedings of the 49th New Zealand Plant Protection Conference: 85-89.

Manktelow D, Stevens P, Walker J, Gurnsey S, Park N, Zabkiewicz J, Teulon D, Rahman A 2005. Trends in Pesticide Use in New Zealand: 2004. Report to the Ministry for the Environment, Project SMF4193. HortResearch Client Report No. 17962, HortResearch, Palmerston North, New Zealand. November 2005. Appendix 9: 49-50.

Martin NA, Beresford RM, Harrington, KC ed. 2005. Pesticide Resistance: Prevention and Management Strategies 2005. New Zealand Plant Protection Society Inc., Hastings, New Zealand. $166 \mathrm{p}$.

Metcalf RL 1993. An increasing public concern. In: The pesticide question, environment, economics, and ethics. Pimentel D, Lehman $\mathrm{H}$ ed. Chapman \& Hall, New York. Pp. 426-430.
Mills WD, LaPlante AA 1954. Apple Scab. In: Disease and insects in the orchard. Cornell Extension Bulletin 711: 20-28.

Mundy DC, Beresford RM 2007. Susceptibility of grapes to Botrytis cinerea in relation to berry nitrogen and sugar concentration. New Zealand Plant Protection 60: 123-127.

Russell PE 2005. A century of fungicide evolution. Journal of Agricultural Science 143: 11-25.

Van Bruggen HC 1995. Plant disease severity in highinput compared to reduced-input and organic farming systems. Plant Disease 79: 976-84.

Viljanen-Rollinson SLH, Marroni MV, Butler RC 2010. Benefits from plant resistance in reducing reliance on fungicides in cereal disease management. New Zealand Plant Protection 63: 145-150.

Walter M, Obanor FO, Smith JT, Ford C, BoydWilson KSH, Harris-Virgin P Langford GI 2007. Timing of fungicide application for Botrytis cinerea control in blackcurrant (Ribes nigrum). New Zealand Plant Protection 60: 114-122.

Whiteman SA, Beresford RM 1998. Evaluation of onion downy mildew disease risk in New Zealand using meteorological forecasting criteria. Proceedings of the $51^{\text {st }}$ New Zealand Plant Protection Conference: 117-122.

Wright PJ, Chynoweth RW, Beresford RM, Henshall WR 2002. Comparisons of strategies for timing protective and curative fungicides for control of onion downy mildew (Peronospora destructor) in New Zealand. Proceedings of the British Crop Protection Conference 2002: 207-212.

Zitter TA 1984. Effect of citizen chemophobia on plant pathology. Plant Disease 68: 655. 